\title{
Spatial-Temporal Characteristics of Glacier Velocity in the Central Karakoram Revealed with 1999-2003 Landsat-7 ETM+ Pan Images
}

\author{
Yongling Sun ${ }^{1,2}$, Liming Jiang ${ }^{1,2, *}$, Lin Liu ${ }^{3}$, Yafei Sun ${ }^{1,2}$ and Hansheng Wang ${ }^{1}$ \\ 1 State Key Laboratory of Geodesy and Earth's Dynamics, Institute of Geodesy and Geophysics, \\ Chinese Academy of Sciences, 340 XuDong Rd, Wuhan 430077, China; \\ sunyongling11@mails.ucas.ac.cn (Y.S.); sunyafei@whigg.ac.cn (Y.S.); lgy@asch.whigg.ac.cn (H.W.) \\ 2 University of Chinese Academy of Sciences, 19A Yuquan Rd., Beijing 100049, China \\ 3 MOE Key Laboratory of Fundamental Physical Quantities Measurement, \\ Hubei Key Laboratory of Gravitation and Quantum Physics, Institute of Geophysics, School of Physics, \\ Huazhong University of Science and Technology, 1037 LuoYu Rd., Wuhan 430074, China; liulin@whigg.ac.cn \\ * Correspondence: jlm@whigg.ac.cn; Tel.: +86-027-8677-8612
}

Received: 26 July 2017; Accepted: 15 October 2017; Published: 19 October 2017

\begin{abstract}
The situation of stable and slightly advancing glaciers in the Karakoram is called the "Karakoram anomaly". Glacier surface velocity is one of the key parameters of glacier dynamics and mass balance, however, the response of glacier motion to this regional anomaly is not fully understood. Here, we characterize the spatial-temporal variations in glacier velocity over the Central Karakoram from 1999-2003. The inter-annual glacier velocity fields were retrieved using a cross-correlation-based algorithm applied to four Landsat-7 Enhanced Thematic Mapper Plus (ETM+) panchromatic image pairs. We find that most of the glaciers on the southern slope flowed faster than those on the northern slope, which might be attributed to the differences in glacier sizes. Furthermore, ice motion observations over four years reveal that most of the glaciers were quasi-stable or experienced small fluctuations of flow velocity during our study period. We identify a new surging event for the South Skamri Glacier in the study period by investigating the glacier frontal changes and the longer-term time series of surface velocities between 1996 and 2006. From the transverse velocity profiles of seven typical glaciers, we infer that basal sliding is the predominant motion mechanism of the middle and upper glaciers, whereas internal deformation dominates closest to the glacier terminus.
\end{abstract}

Keywords: Central Karakoram; glacier velocity; spatial-temporal variations; local morphometric effects; motion mechanism; Landsat-7 ETM+ panchromatic image

\section{Introduction}

Field observations and geodetic measurements suggest that glaciers in the Karakoram Range are either stable or have been expanding since 1990 and present positive or less negative mass changes [1-8]. This situation is called the "Karakoram anomaly" [7]. As one of the most glaciated regions outside of the polar regions [9], the Central Karakoram has experienced a slight gain in glacier mass at the beginning of the 21st century $[4,10]$. The snow and glacial melt in this region is an important source of water for the Indus River in Pakistan [11,12] and the Yarkant River in China [13]. Glacier dynamics in the Central Karakoram have a significant influence on the hydrological cycle, especially hydrological planning and water resource management. As one of the crucial factors in mass balance and glacier dynamics [14], the glacier surface velocity provides an indicator of glacier recession or advance/surge [15-17] and has been used to interpret glacier dynamics [18]. Therefore, the spatial-temporal characteristics of the glacier velocity in this region are essential to improve our understanding of glacier dynamics and the glacier responses to climate change and influences on regional water sources. 
Several studies have investigated the temporal variations of glacier velocity in the Central Karakoram and most of them focused on individual glaciers. Quincey et al. [19] showed that the velocity of the Baltoro Glacier increased from 1992-2005 and then decreased from 2005-2008 as derived from SAR images of ERS and ENVISAT ASAR; however, they did not provide the velocity results from 1999-2003. Mayer et al. [15] discovered that the North Gasherbrum Glacier advanced from 2003-2007 through an analysis of the annual average glacier velocities obtained from Landsat images. Scherler et al. [20] presented surface velocity results of the Biafo Glacier from ASTER images acquired from 2000-2009 and reported that the highest velocity occurred in 2005. Paul [16] used animated sequences of orthorectified satellite images, which were acquired from 1990-2015, to demonstrate glacial dynamics in the Central Karakoram. This provided an insight into the dynamic glacier behaviour on a different way (although this may be a less quantitative approach). Recently, Heid et al. [21] used two pairs of Landsat Enhanced Thematic Mapper Plus (ETM+) images (2000/2001) and Landsat Thematic Mapper (TM) images (2009/2010) to map the ice flow velocities of the Central Karakoram and found a slight increase in glacier velocity between the two epochs of observation. Dehecq et al. [22] derived the glacier velocity field for the year 2000 over the entire Karakoram by employing all of the available archived Landsat 5 and 7 images to improve the percentage of successful measurements and reduce the uncertainty of the velocity field. Overall, inter-annual variations of glacier velocity in the Central Karakoram are still limited, especially at the beginning of the 21st century.

The extremely rugged topography of the Central Karakoram, which is home to more than sixty peaks that are more than $7000 \mathrm{~m}$ above sea level (a.s.l.), has the complex effects of the southern and northern slopes on glacier dynamics [14]. Copland et al. [23] noted that there were insignificant differences in the ice velocities of glaciers on the southern and northern slopes in the period from 2006-2007. The velocity maps in Heid et al. [21], Rankl et al. [1] and Dehecq et al. [22] showed higher velocities in glaciers on the southern slope; however, they did not quantitatively estimate the velocity difference between the southern and northern glaciers. A comparison of the velocity results reported in Copland et al. [23], Mayer et al. [15], and Quincey et al. [19] indicate that the maximum ice rates of the Skamri Glacier (250 m/year) and the North Gasherbrum Glacier (401 m/year) located on the northern slope were higher than that of the Baltoro Glacier $(190 \mathrm{~m} /$ year) on the southern slope in the same period of 2006-2007. Consequently, the velocity variations between glaciers on the southern and northern slopes and their potential reasons are not yet fully understood and further studies are required.

The main aim of this study is to characterize the spatial-temporal variability of glacier surface velocity over the Central Karakoram in the period from 1999-2003. The inter-annual glacier velocity results are achieved by using a cross-correlation algorithm with four pairs of Landsat-7 Enhanced Thematic Mapper Plus panchromatic images (Table 1). These results are put into a broader context of glacial dynamics in the Central Karakoram and thus enable a narrowing of the knowledge gaps with regard to glacier velocity variations in this region at the beginning of the 21st century. We also aim to analyse the ice flow velocity of major glaciers on the southern and northern slopes as a function of multiple topographic factors (size, median elevation, slope and aspect), and further estimate the influence of debris cover. Finally, the ice motion mechanisms of seven typical glaciers are discussed based on the velocity distribution patterns along the glacier transverse profiles.

\section{Study Area}

The study area (from $35^{\circ} \mathrm{N}$ to $36.5^{\circ} \mathrm{N}$ and from $75.5^{\circ} \mathrm{E}$ to $77.5^{\circ} \mathrm{E}$ ) is situated in the Central Karakoram and covers a glaciated region of more than $5800 \mathrm{~km}^{2}$, which is estimated based on the glacier area from the Randolph Glacier Inventory (RGI v5.0) [24]. The Central Karakoram is an area with significant topography and extreme relief that is home to more than sixty peaks that are higher than $7000 \mathrm{~m}$ a.s.l. [25]. Four of these peaks exceed $8000 \mathrm{~m}$ a.s.l. including K2 (the second highest peak in the world at $8611 \mathrm{~m}$ a.s.l.), Gasherbrum I (8068 m a.s.1.), Broad Peak (8047 m a.s.l.), and Gasherbrum II (8035 $\mathrm{m}$ a.s.l.). This region is also one of the most heavily glaciated parts of the world outside of 
the polar regions and contains more than 30 glaciers over $20 \mathrm{~km}$ in length, some of which are the longest mountain glaciers on Earth outside of the Polar Regions, e.g., Siachen Glacier $(76 \mathrm{~km})$ and the Biafo Glacier $(68 \mathrm{~km})$ rank as the longest and second longest glaciers in the Karakoram [26,27]. Generally, the glaciers of the Central Karakoram are divided into two groups by the main ridge (see Figure 1). One group is located on the southern slope and includes the Biafo, Baltoro, Siachen, Kaberi, and Panmah glaciers. The other group on the northern slope mainly contains the Braldu, Skamri, Sarpo Laggo, North Gasherbrum, Urbak, Singkhu, and Kyagar glaciers. The name of each glacier is based on RGI v5.0 [24] and partly on Paul [16]. As the hillslope-erosion rates usually increase with hillslope angle, high and deeply incised mountain relief results in thick debris that covers most of the glaciers in this region [28].

The regional climate of the Central Karakoram is influenced by the varying dominance of westerlies and the Indian monsoon $[5,25]$ and has a considerable microclimatic variability influenced by the high mountain terrain $[26,29]$. In the northwest, two-thirds of the high-altitude snowfall in the Central Karakoram in winter is contributed by westerlies. However, in the southeast, $80 \%$ of the summer precipitation is provided by the Indian monsoon $[1,5,25]$. Since the 1990s, relative stability or even an advance for many glaciers has been observed across the Central Karakoram [1,2,4,7], which may have been induced by strengthening westerlies [2,30]. Recently, several studies focused on the velocities of the glacier in the Central Karakoram and reported that a velocity change was associated with climate change, e.g., Quincey et al. [19] and Scherler et al. [20] all reported that the peak velocities in 2005 of Baltoro Glacier and Biafo Glacier are related to the precipitation.

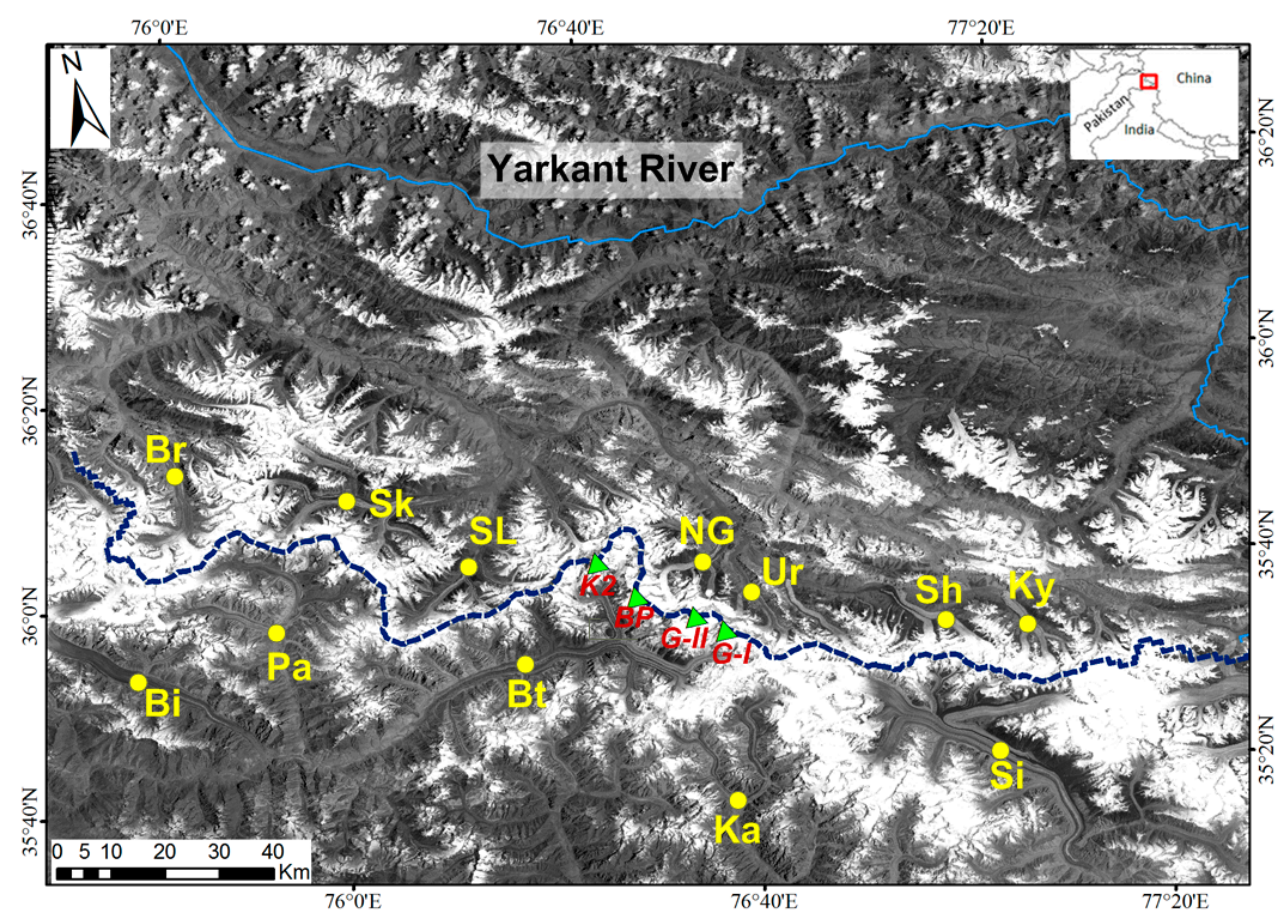

Figure 1. An overview of the study area. The background is the Landsat ETM+ image acquired on 21 July 2001. The blue line marks the Yarkant River, and the blue dashed line marks the boundary between glaciers on the southern and northern slopes. The green triangles represent four peaks (exceeding $8000 \mathrm{~m}$ a.s.l.) from north to south: K2, Broad Peak, Gasherbrum II and Gasherbrum I. The yellow points mark the glaciers mentioned in context. Abbreviations: $\mathrm{Br}=\mathrm{Braldu}$ Glacier, Sk = Skamri Glacier, SL = Sarpo Laggo Glacier, NG = North Gasherbrum Glacier, Ur = Urbak Glacier, $\mathrm{Sh}=$ Singkhu Glacier, Ky = Kyagar Glacier, $\mathrm{Si}=$ Siachen Glacier, Ka = Kaberi Glacier, Bt = Baltoro Glacier, $\mathrm{Pa}=$ Panmah Glacier, $\mathrm{Bi}=$ Biafo Glacier. 


\section{Data and Methods}

\subsection{Landsat-7 ETM+ Datasets}

In this study, we utilized Landsat-7 ETM+ images acquired from 1999-2003 to estimate the glacier surface velocity over the Central Karakoram. The Enhanced Thematic Mapper Plus is one of the main instruments on board the Landsat-7 satellite, which was successfully launched on 15 April 1999. The ETM+ image has a relatively short revisit of 16 days and a large coverage scene $(185 \mathrm{~km} \times 170 \mathrm{~km})$. Additionally, the Landsat-7 ETM+ sensor offers several enhancements over the Landsat-4, 5 TM sensor including improved geometric accuracy, reduced noise, reliable calibration, the addition of a panchromatic band $(15 \mathrm{~m})$, and increased spectral information content. The ETM+ images are a potential source of remotely sensed data for monitoring mountain glacier dynamics.

Table 1 lists the Landsat-7 ETM+ images over the study area acquired between 1999 and 2003. The four pairs of panchromatic images used in this study were in the same path/row (148/35) to minimize geometric distortions. Additionally, the time interval of the four image pairs was almost one year to reduce the seasonal effects and the influence of the sun altitude. Thus, the similar glacier surface condition between the two acquisitions could improve the accuracy of the glacier velocity estimation. We tried to select the images acquired in summer with the lowest percentage cloud cover. However, the ETM+ scan line corrector failed in May 2003 [31], and resulted in no suitable images available in the summer for 2003. Therefore, the image pair used for 2002/2003 was acquired in spring. The Landsat ETM+ images were downloaded from the United States Geological Survey (USGS) EarthExplorer [32].

Table 1. Landsat ETM+ image pairs used in this study.

\begin{tabular}{cccc}
\hline Sensor & Date Image t1 & Date Image t2 & Path/Row \\
\hline Landsat ETM+ & 16 July 1999 & 16 June 2000 & $148 / 35$ \\
Landsat ETM+ & 16 June 2000 & 21 July 2001 & $148 / 35$ \\
Landsat ETM+ & 21 July 2001 & 9 August 2002 & $148 / 35$ \\
Landsat ETM+ & 19 April 2002 & 21 March 2003 & $148 / 35$ \\
\hline
\end{tabular}

\subsection{Methodology and Data Processing}

The glacier surface displacement measurements were calculated using the cross-correlation algorithm in the frequency domain proposed by Leprince et al. [33] which has already shown good results for similar glacier applications [20,34,35]. This method relies on the identification of surface features across two time-separated satellite scenes. It consists of three key processing steps: (i) orthorectification; (ii) co-registration; and (iii) correlation. The Landsat image was provided at Level 1T (L1T), which was already orthorectified by USGS; consequently, we did not conduct the orthorectification for our data processing $[35,36]$. The images were co-registered in ENVI software, and the horizontal displacements were calculated with the COSI-Corr software package [37]. The principle of the cross-correlation algorithm in the frequency domain can be found in Leprince et al. [33].

In this paper, horizontal displacements along the East/West (E/W) and North/South (N/S) directions were derived from this cross-correlation algorithm using a $64 \times 64$ (pixels) window as the initial search window and a $32 \times 32$ (pixels) window as the final window. The optimal window size was obtained after extensive testing. Patches with the largest window size were correlated first, and the correlation process was conducted iteratively until the minimum window size was reached or until the correlation failed. Moreover, to avoid the occurrence of a correlation bias, a frequency mask was applied to only select parts of the cross-spectrum where the phase information was valid. The mask parameter was set to 0.9 and five robustness iterations were applied. Finally, the results with a ground resolution of $30 \mathrm{~m}$ (a sliding step of two pixels for the correlation window) obtained by the correlation process included 2D horizontal glacier motion fields along the E/W and N/S directions, and the Signal-to-Noise Ratio (SNR) images corresponding to the measurements. A Non-Local Means 
Filter was applied to reduce noise, which is implemented in the COSI-Corr software package. In this study, the noise parameter of the filter was set to 1.6 times of the estimated standard deviation, the search area set to $21 \times 21$ pixels, and the patch size set to $5 \times 5$ pixels. The $2 \mathrm{D}$ glacier velocities were derived by dividing the horizontal ground displacements along the $\mathrm{E} / \mathrm{W}$ and $\mathrm{N} / \mathrm{S}$ directions by the time interval between the two images.

\subsection{Accuracy Estimation}

The main error sources of the cross-correlation algorithm included (1) the image quality (i.e., snow cover, cloud cover and melting glaciers); and (2) the image registration errors. Due to a lack of in situ measurements of the glacier velocity, it was difficult to directly assess the results of the cross-correlation algorithm. Considering the stable properties of off-glacier areas that should not be displaced, the displacements of the off-glacier area have been widely used to evaluate the cross-correlation performance. Here, we used a method similar to the one adopted by the cited references $[38,39]$. By assuming that the off-glacier area was stable (namely, no displacement), the error of the displacements in the off-glacier area is:

$$
e_{o f f}=\sqrt{S E^{2}+M E D^{2}}
$$

$e_{o f f}$ is the error of displacement, $M E D$ is the mean displacement, and $S E$ is the standard error of the mean displacement, as the computation formula below:

$$
S E=\frac{S T D V}{\sqrt{N_{e f f}}}
$$

$S T D V$ is the standard deviation of the mean displacement in the off-glacier area; $N_{e f f}$ represents the number of independent measurements and its computation formula is:

$$
N_{e f f}=\frac{N_{t o t a l} \times P S}{2 D}
$$

where PS represents the pixel size and $D$ is the distance of spatial autocorrelation. According to experience, $D$ is approximately 20 times as much as $P S[38]$.

\section{Results}

\subsection{Spatial Pattern of the Glacier Velocity}

Figure 2 illustrates the average results of the glacier velocity fields over the Central Karakoram derived from four annual pairs (Table 1). For better visualization, the results were masked by the glacier inventory of RGI 5.0 [24] and were overlaid on the hillshade image of SRTM DEM [32]. The average annual velocities show the main characteristics of glacier flow dynamics. In general, the large-sized glaciers flowed faster than the small glaciers, and there was a general increase in velocity from the glacier terminus to the upper area. The maximum velocity reached approximately $200 \mathrm{~m} /$ year at the Biafo glacier and the South Skamri Glacier from 1999-2003. The uncertainty of the velocity results based on the off-glacier statistics was approximately $\pm 7 \mathrm{~m}$ /year in the four epochs of observation, which is less than one-half a pixel. This is comparable with those errors reported in the scientific literature $[19,20]$ and demonstrates the reliability of the results in this study. 


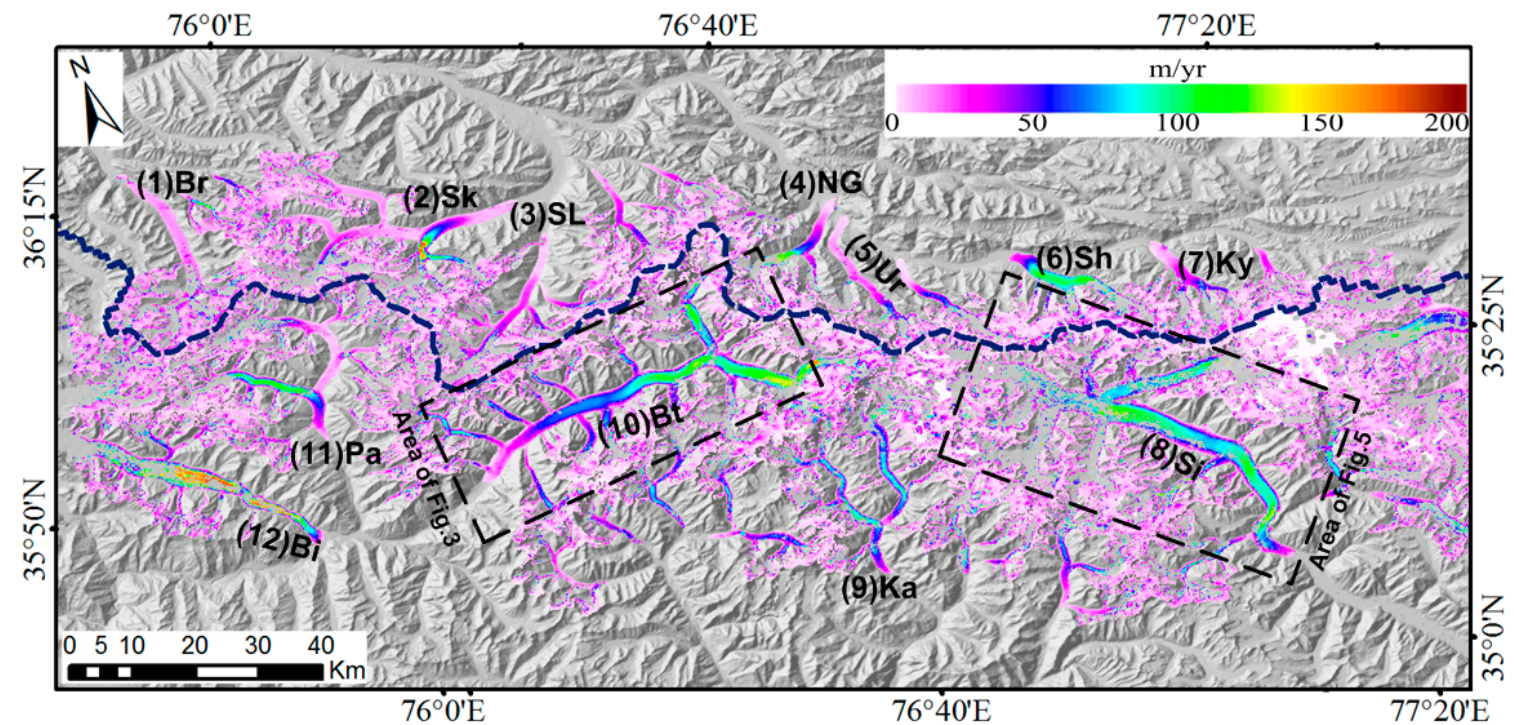

Figure 2. Average annual velocity field across the Central Karakoram from 1999-2003. The background is the hillshade image of SRTM DEM. The blue dashed line marks the boundary between the southern and northern slopes' glaciers. Abbreviations: $\mathrm{Br}=$ Braldu Glacier, $\mathrm{Sk}=$ Skamri Glacier, $\mathrm{SL}=$ Sarpo Laggo Glacier, NG = North Gasherbrum Glacier, Ur = Urbak Glacier, $\mathrm{Sh}=$ Singkhu Glacier, $\mathrm{Ky}=$ Kyagar Glacier, $\mathrm{Si}=$ Siachen Glacier, $\mathrm{Ka}=$ Kaberi Glacier, $\mathrm{Bt}=$ Baltoro Glacier, $\mathrm{Pa}=\mathrm{Panmah}$ Glacier, $\mathrm{Bi}=$ Biafo Glacier.

For most of the studied glaciers, the results of ice flow velocity in the ablation areas are more reliable than those in the accumulation areas where the trackable features are lacking and the variability of the snow extent is high (as shown in Figure 1). To detect the spatial variations in ice flow velocity between glaciers on the southern and northern slopes, we analysed the annual average velocities from 1999-2003 along the glacier centerlines over ablation areas of twelve major glaciers with an area larger than $80 \mathrm{~km}^{2}$ (Table 2). As the glaciers are different in size, we calculated the average velocities that limited to the lower $30 \%$ of the glacier length along the centerline for each glacier, in which there are relatively reliable velocity data for most glaciers. Table 2 suggests that the average velocities of the southern-slope glaciers were much higher than those of the northern-slope glaciers, except for the Singkhu Glacier. The average velocity of the five southern-slope glaciers was $77.42 \mathrm{~m} /$ year, whereas it was $29.92 \mathrm{~m} /$ year for the seven glaciers on the northern slope. This difference could be attributed to the different topographic influences between the southern and northern slopes. The relationship between the glacier velocity and these factors are discussed in detail in Section 5.3. 
Table 2. Average centerline velocities (limited to the lower 30\% of the glacier length along the centerline) of major glaciers over the Central Karakoram from 1999-2003, and average annual velocity during 2007-2011 reported by Rankl et al. [1]. NS denotes that the glaciers locate on the northern slope and SS denotes that the glaciers locate on the southern slope. $\mathrm{s}=$ surge-type glacier, $\mathrm{n}=$ normal glacier. The locations of the numbered glaciers are marked in Figure 2 .

\begin{tabular}{|c|c|c|c|c|c|c|c|c|c|c|}
\hline No. & Glacier & Type & $\begin{array}{l}\text { Length of Centerline } \\
(\mathrm{km}) / \text { Altitude of the } \\
\text { Start (m) }\end{array}$ & $\begin{array}{c}\text { 1999-2000 } \\
\text { Velocity } \\
\text { (m/yr) }\end{array}$ & $\begin{array}{c}\text { 2000-2001 } \\
\text { Velocity } \\
\text { (m/yr) }\end{array}$ & $\begin{array}{l}\text { 2001-2002 } \\
\text { Velocity } \\
(\mathrm{m} / \mathrm{yr})\end{array}$ & $\begin{array}{l}2002-2003 \\
\text { Velocity } \\
(\mathrm{m} / \mathrm{yr})\end{array}$ & $\begin{array}{l}\text { Diff. between } \\
\text { Max. and Min. } \\
(\mathrm{m} / \mathrm{yr})\end{array}$ & $\begin{array}{c}\text { 1999-2003 } \\
\text { Average Velocity } \\
(\mathrm{m} / \mathrm{yr})\end{array}$ & $\begin{array}{c}2007-2011 \\
\text { Average Velocity } \\
(\mathrm{m} / \mathrm{yr})\end{array}$ \\
\hline 1 & Braldu (NS) & $\mathrm{s}$ & $10.79 / 3963$ & 16.17 & 13.44 & 12.06 & 17.19 & 5.13 & 14.72 & No data \\
\hline 2 & Skamri (NS) & $\mathrm{s}$ & $12.35 / 3995$ & 36.60 & 51.43 & 35.61 & 43.92 & 15.82 & 41.89 & 58.34 \\
\hline 3 & Sarpo Laggo(NS) & $\mathrm{s}$ & $8.97 / 4289$ & 13.02 & 19.36 & 7.42 & 13.22 & 11.94 & 13.26 & No data \\
\hline 4 & North Gasherbrum (NS) & $\mathrm{s}$ & $7.75 / 4299$ & 21.67 & 25.93 & 25.97 & 34.75 & 13.08 & 27.08 & 71.89 \\
\hline 5 & Urbak (NS) & $\mathrm{s}$ & $8.12 / 4468$ & 11.70 & 10.20 & 3.78 & 23.80 & 20.02 & 12.37 & 5.73 \\
\hline 6 & Singkhu (NS) & $\mathrm{s}$ & $8.07 / 4519$ & 91.24 & 79.61 & 72.48 & 78.37 & 18.76 & 80.43 & 83.14 \\
\hline 7 & Kyagar (NS) & $\mathrm{s}$ & $6.44 / 4891$ & 24.52 & 23.13 & 10.88 & 20.32 & 13.64 & 19.71 & 13.66 \\
\hline 8 & Siachen (SS) & $\mathrm{n}$ & $22.89 / 3698$ & 94.48 & 89.10 & 89.67 & 90.99 & 5.38 & 91.06 & 90.97 \\
\hline 9 & Kaberi (SS) & $\mathrm{n}$ & $12.24 / 3218$ & 67.37 & 66.06 & 66.46 & 68.92 & 2.86 & 67.20 & 51.84 \\
\hline 10 & Baltoro (SS) & $\mathrm{n}$ & $19.03 / 3525$ & 55.06 & 49.13 & 46.98 & 48.95 & 8.08 & 50.03 & 75.23 \\
\hline 11 & Panmah (SS) & $\mathrm{n}$ & $9.99 / 3593$ & 55.15 & 60.35 & 55.99 & 47.29 & 13.06 & 54.70 & No data \\
\hline 12 & Biafo (SS) & $\mathrm{n}$ & $20.34 / 3184$ & 138.97 & 123.04 & 119.50 & 114.90 & 24.07 & 124.10 & 92.53 \\
\hline
\end{tabular}




\subsection{Temporal Changes of Glacier Velocity during 1999-2003}

Figure S1 in the Supplementary Material illustrates the annual velocity results of the glaciers in the Central Karakoram for four epochs from 1999-2003. Overall, the variations in ice velocities from 1999-2003 are not obvious for most of the studied glaciers including surge-type and non-surge-type glaciers. Table 2 quantitatively reveals the fluctuations of ice motion for 12 major glaciers on the southern and northern slopes. Using a similar method that was proposed in [28] to identify whether glacier front was stable or not, we estimate fluctuation status of flow velocity of the 12 major glaciers with the difference between the maximum and minimum of annual velocities. Since the uncertainties in the derived glacier velocities are $\sim 7.0 \mathrm{~m} /$ year (see Section 4.1 ), the uncertainty of difference between the maximum and minimum of annual velocity for a glacier is less than $10 \mathrm{~m} /$ year according to the linear error propagation law, which we thus take as a lower bound to discriminate stable-flow glacier from fluctuant glacier in velocity. According to Table 2, the ice motion of Braldu, Siachen, Kaberi and Baltoro glaciers are quasi-stable, while the other glaciers (except for Urbak and Baifo glaciers) experienced slight fluctuations during the study period. It is worth noting that there are several surge-type glaciers in this area $[1,15,40]$ (particularly on the northern slope), which undergo non-steady flow with alternations between active phases and the quiescent phase. Most of the inventoried surge-type glaciers in the study area (e.g., the Braldu, Skamri, Sarpo Laggo, North Gasherbrum, Urbak and Kyagar glaciers) experienced relatively small rates of motion (Supplementary Figure S1; Table 2); however, the Singkhu glacier flowed fast compared with the other surge-type glaciers. The surge dynamics of such surge-type glaciers will be discussed in detail in Section 5.2.

We focus on Baltoro Glacier and the Siachen Glacier in the analysis of inter-annual velocity variations from 1999-2003, as they have relatively complete spatial-coverage of ice velocity. Additionally, the time series of the annual velocity fields of the North Gasherbrum Glacier and Singkhu Glacier are presented in Supplementary Figures S2 and S4, and the annual speed profiles along the centerlines of the two glaciers are presented in Supplementary Figures S3 and S5. The ice motion of the North Gasherbrum Glacier slightly increased from 1999/2000 to 2002/2003, while the Singkhu Glacier experienced velocity decrease during 1999-2003.

\subsubsection{Baltoro Glacier}

Figure 3 illustrates the annual velocity fields of the Baltoro Glacier for four years from 1999-2003. Relatively complete coverage of the ice flow fields was retrieved from the glacier trunk and most of its tributaries even though the velocity results in 2002/2003 were obtained from ETM+ images acquired in spring. As shown in Figure 4, the speed generally increased with increasing elevation and with a maximum speed $(160 \mathrm{~m} /$ year) of approximately $45 \mathrm{~km}$ from the terminus. A peak surface speed of $140 \mathrm{~m} /$ year was found below the area of Concordia (Figure 3a), the confluence of the Baltoro South and North tributaries, which is mainly related to the extra ice flow from the two tributaries. However, the velocity quickly decreased as the centerline profile extends up the south tributary. The annual velocities range from $46.98 \mathrm{~m}$ /year to $55.06 \mathrm{~m}$ /year during 1999-2003 (Table 2), indicating that the ice motion of this glacier was small. Figure 4 also shows that the velocities are almost independent of the slopes ( $<10$ degree) along the $45-\mathrm{km}$-long centerline profile from the terminus. 

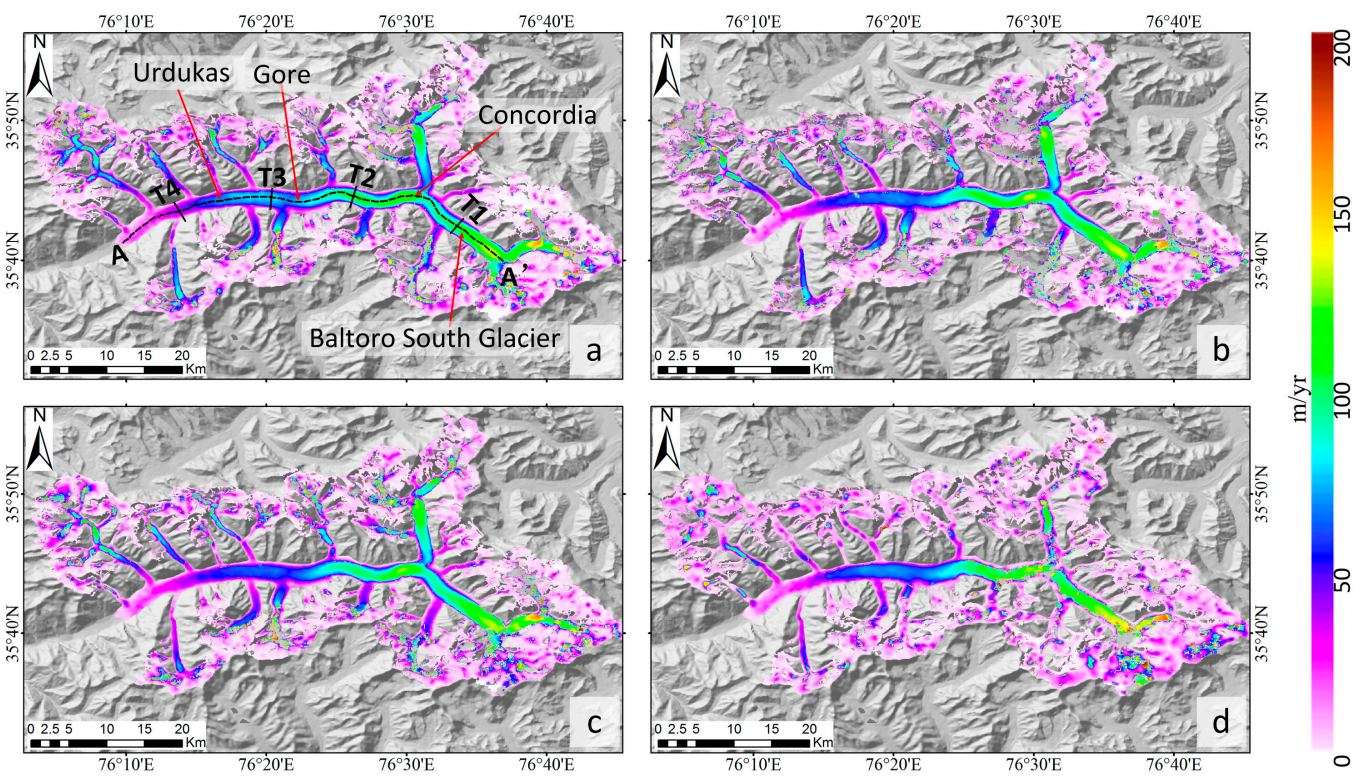

Figure 3. Four annual velocity fields of the Baltoro Glacier and its tributaries from 1999-2003. (a) 1999-2000; (b) 2000-2001; (c) 2001-2002; and (d) 2002-2003. The background is the hillshade image of SRTM DEM. AA' is the centerline of the glacier and T1, T2, T3, and T4 are the transverse profile's locations.

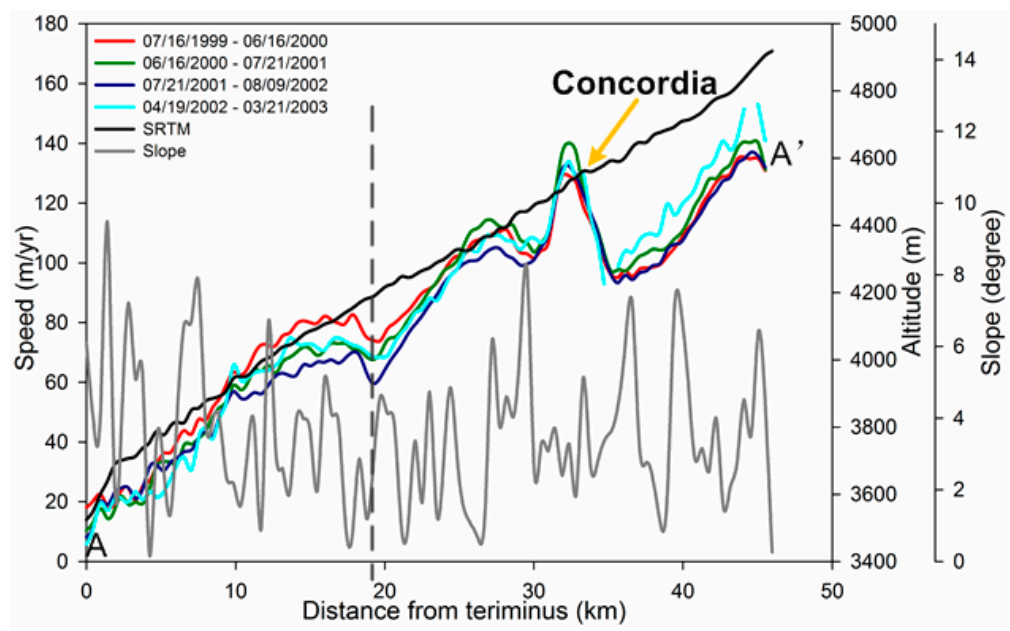

Figure 4. Annual speed profiles along the centerline ( $\left.\mathrm{AA}^{\prime}\right)$ of the Baltoro Glacier. The centerline location is indicated by the dashed line in Figure 3a. The gray dashed line marks the end-point location of the centerline profile for average velocity estimation in Table 2.

\subsubsection{Siachen Glacier}

Figure 5 shows temporal variations in the annual velocity of the Siachen Glacier from 1999-2003. Compared with the Baltoro Glacier, the insufficient trackable features resulted in less complete coverage of the velocity fields for the Siachen Glacier, especially in its accumulation region. Similar to the Baltoro Glacier, the ice motion of Siachen Glacier underwent small fluctuations from 1999-2003 with no obvious changes in multi-temporal velocities. This temporal pattern was also present in the annual velocity profiles along the glacier centerline (BB') (Figure 6). Figure 6 shows that the glacier motion rates are generally dependent on elevation but two peaks are found at approximately $8.7 \mathrm{~km}$ and $17.5 \mathrm{~km}$ from the terminus with speeds of approximately $140 \mathrm{~m} /$ year and $105 \mathrm{~m} /$ year. These might result from the change of ice flow direction and the narrow width of the glacier. With a further 
increase of elevation, the speed decreased and dropped to its minimum (70 m/year) at approximately $24 \mathrm{~km}$ from the terminus. The maximum velocity that located at $40 \mathrm{~km}$ is mainly attributed to that many tributary glaciers feed this area, especially the Teram Shehr and Lolofond glaciers (Figure 5a). As shown in Figure 6, the slopes along the centerline are small ( $<8$ degrees), and there is no obvious correlation between the slope (along the 42-km-long centerline profile from the terminus) and the speed of the Siachen Glacier.
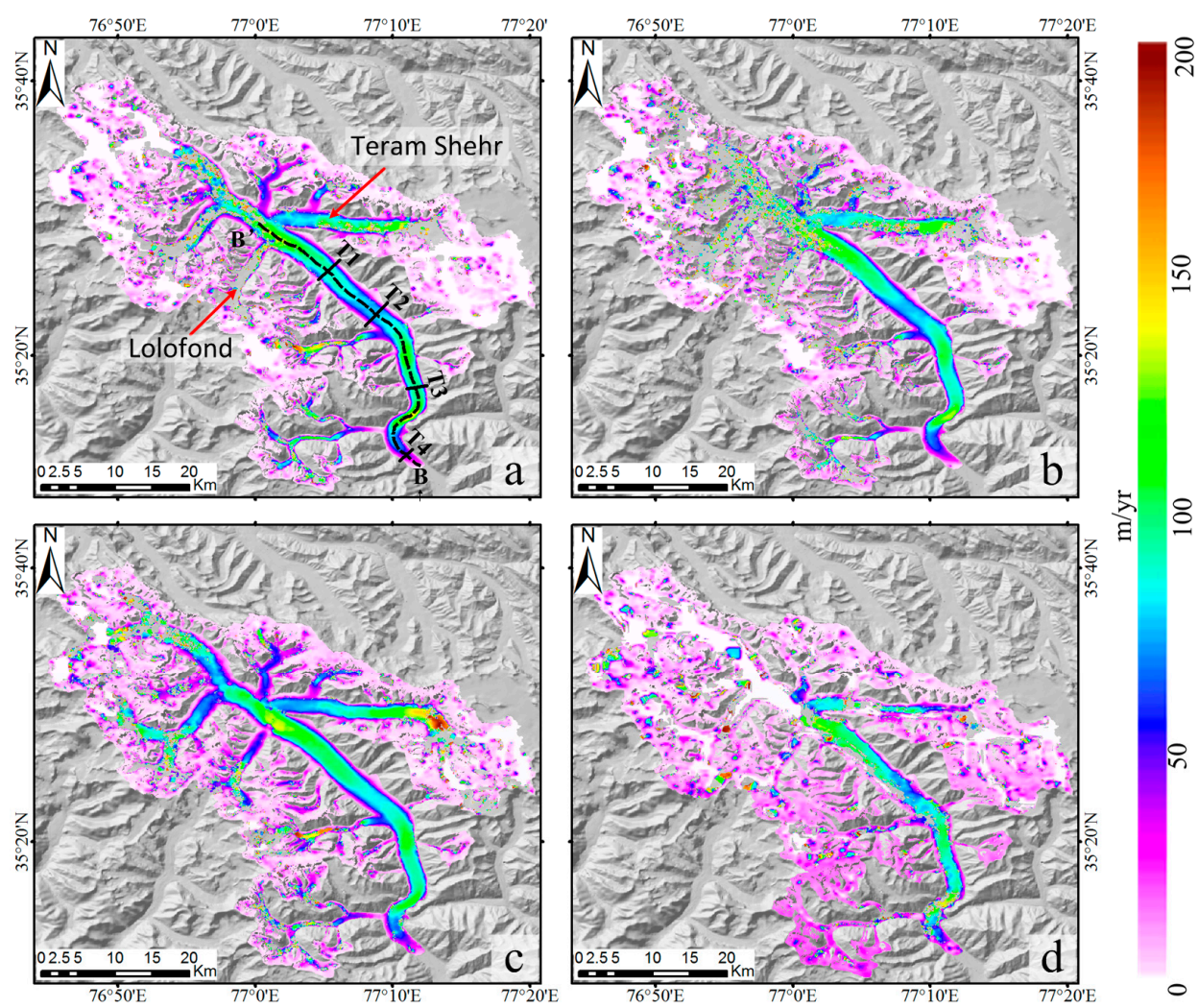

Figure 5. Four annual velocity fields of the Siachen Glacier and its tributaries from 1999-2003. (a) 1999-2000; (b) 2000-2001; (c) 2001-2002; and (d) 2002-2003. The background is the hillshade image of SRTM DEM. BB' is the centerline of the glacier, and T1, T2, T3, and T4 are the transverse profile's locations.

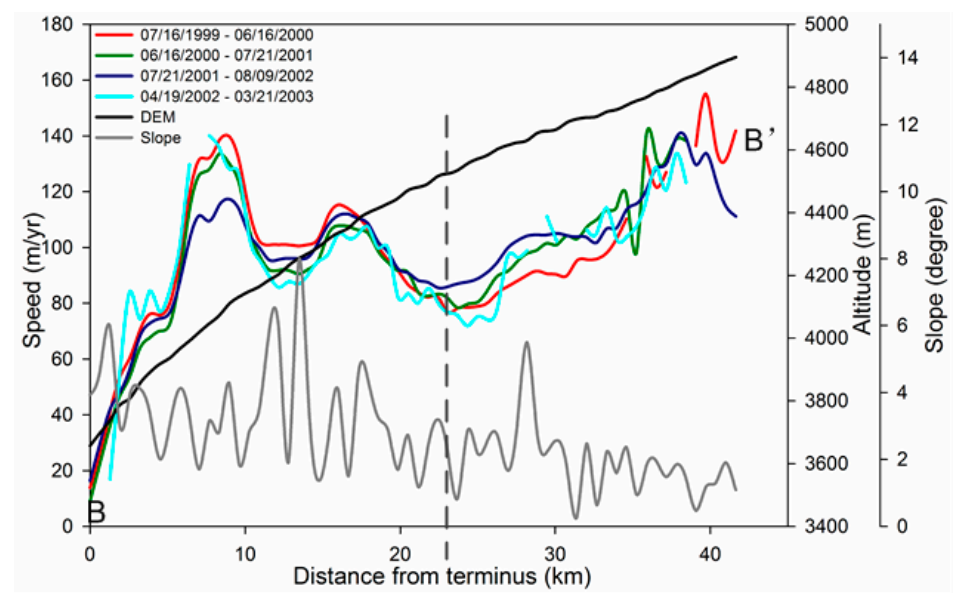

Figure 6. Annual speed profiles along the centerline (BB') of the Siachen Glacier. The centerline location is indicated by the dashed line in Figure 5a. The gray dashed line marks the end-point location of the centerline profile for average velocity estimation in Table 2. 


\section{Discussion}

\subsection{A Comparison with Previous Studies}

To analyse the temporal changes, we compared our velocity results with previous studies. A quantitative comparison analysis for major glaciers in the study area was performed between our velocity results (1999-2003) and the velocity measurements (2007-2011) provided by Dr. Rankl, who compiled surface velocities mosaic for a Karakoram-wide coverage derived with the SAR dataset between 2007 and 2011 [1]. As shown in Table 2, in general, the average annual velocities of most glaciers for the two epochs have small fluctuations or slight increases. Note that the average velocity of the North Gasherbrum Glacier during 2007-2011 is up to $71 \mathrm{~m} /$ year and is 2.5 times as high as the velocity of $\sim 27 \mathrm{~m} /$ year during 1999-2003. This significant velocity difference might be due to the different surge phases of the glacier for the two epochs, and more details will be discussed in Section 5.2. Moreover, the velocity for the Biafo Glacier decreased from $124 \mathrm{~m} /$ year in 1999/2003 to $\sim 92 \mathrm{~m} /$ year in 2007/2011, and these variation patterns are comparable with those averaged velocity variations during the period from 2001-2009 in Scherler et al. [20]. This indicates that the large velocity fluctuations for the Biafo Glacier, as reported in Scherler et al. [20], might occur during a longer period from 1999 to 2011.

Regarding the well-investigated Baltoro Glacier, the average velocity in 2007/2011 was 50\% higher than that in 1999/2003 as shown in Table 2, whereas Quincey et al. [19] reported that the velocity in 2006/2008 was 15-20\% greater than that in the early 2000s. This suggests that the Baltoro Glacier might speed up slightly from 2008 to 2011. In addition, the annual velocity profiles along the centerline of the Baltoro Glacier (Figure 4) are generally in agreement with the previous study in Quincey et al. [19], which reported a clear variability of ice flow across the entire glacier. In particular, flow profiles for the lowermost $10 \mathrm{~km}$ of the glacier terminus show a strong consistency between our results (from 1999-2003) and the previous results (2003-2008) reported by Quincey et al. [19]. However, the greatest differences between the two results were in the area around Concordia (the Concordia location is marked in Figure 3), where the 1999-2003 annual velocities of $~ 140 \mathrm{~m} /$ year increased to $160 \mathrm{~m} /$ year from 2003-2005 (see Quincey et al. [19], Figure 4). Such velocity variations imply that the speed-up of the glacier around Concordia and as reported in Quincey et al. [19] might start in 1999.

The velocity fluctuations for the Siachen Glacier are insignificant from 1996-2011 based on the comparison of our results with those published in the literature. Kumar et al. [27] derived the velocities of the Siachen Glacier from two pairs of ERS images using the Differential Interferometry SAR (D-InSAR) method. They found that the maximum velocity of the glacier was $43.00 \mathrm{~cm} / \mathrm{d}$ (equating to $156.00 \mathrm{~m} /$ year) in 1996 at about $40 \mathrm{~km}$ from the terminus (Figure 6a). This is comparable to the velocity at the same area ( 150 m/year, Figure 6a) in our study. Rankl et al. [1] recorded a velocity of approximately $0.47 \mathrm{~m} / \mathrm{d}$ (equating to $171.55 \mathrm{~m} /$ year) in the middle and upper areas of the Siachen Glacier from 2007-2011, through an SAR offset tracking algorithm. Moreover, the velocity results derived from the D-InSAR algorithm on the upstream area of the Siachen Glacier are better than the downstream area due to low coherence [27]. In contrast, our results from the cross-correlation algorithm show a more complete coverage of ice velocity in the downstream area with lots of null values occurring on the upstream area covered by snow. Therefore, if there are contemporary SAR and optical images available, a combination of the two methods may obtain a more complete ice flow field of the Siachen Glacier.

\subsection{Surge-Type Glacier Dynamics}

There are many surge-type glaciers in the Central Karakoram [1,15,16,23,40-43] including Braldu Glacier, Skamri Glacier, North Gasherbrum Glacier, Sarpo Laggo Glacier, Singkhu Glacier, Urbak Glacier, and Kyagar Glacier. Most of these surge-type glaciers experienced relatively small motion rates, which implies that these glaciers might be in their quiescent phases during our observation 
period. Due to incomplete velocity fields of small surge-type glaciers, we focused our discussion on the North Gasherbrum, Singkhu and Skamri glaciers.

The North Gasherbrum Glacier was identified as a surge-type glacier by Kotlyakov [44]. Quincey et al. [41] reported that a glacier surge was initiated in the autumn of 2005 with a peak velocity of $0.5 \mathrm{~km} / \mathrm{yr}$ (equating to $500 \mathrm{~m} /$ year) in the summer of 2006, which agreed with Mayer et al. [15] who found that this glacier advanced from 2003-2007. As shown in Table 2, the velocities of the North Gasherbrum Glacier were relatively small and increased from $21.67 \mathrm{~m} /$ year (1999/2000) to $34.75 \mathrm{~m} /$ year (2002/2003). Compared with Quincey et al. [41] and Mayer et al. [15], it can be inferred that the North Gasherbrum Glacier might have experienced a quiescent phase over the period from 1999-2003. Moreover, the significant velocity difference between our result and Rankl et al. [1] is mainly attributed to the fact that the North Gasherbrum Glacier surged during 2007-2011. In addition, the Singkhu Glacier exhibited relatively high velocities during the study period. Due to the limited velocity results of this glacier in the published literature, we analysed the annual speeds along the centerline of the Singkhu Glacier during 1996-2006 from the Landsat TM and ETM+ images (Figure 7). The result indicates that the Singkhu Glacier might have undergone a quiescent phase during the study period due to no significant surge signal. The velocity of the Singkhu Glacier from 2007-2011 (Table 2) is comparable with our results, which indicate that this glacier was also in its quiescent phase from 2007 to 2011.
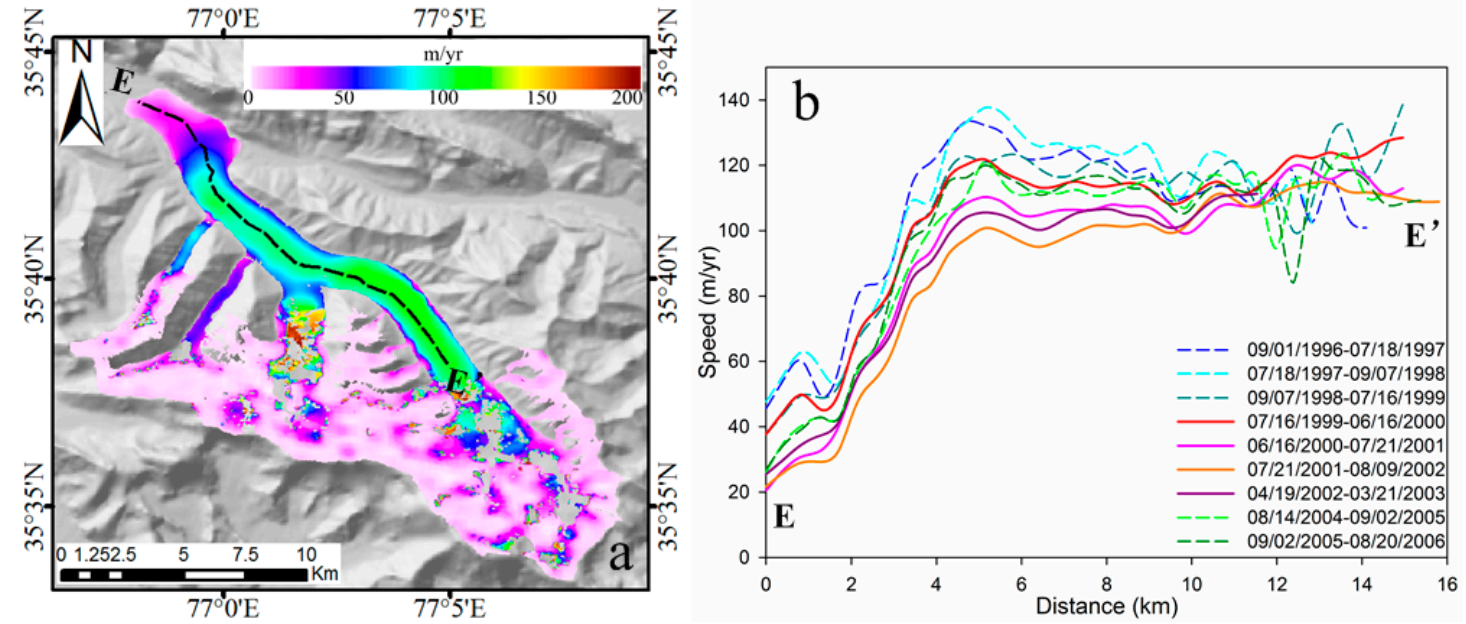

Figure 7. (a) Surface velocity over the Singkhu Glacier (2001-2002) and $E E^{\prime}$ is the centerline of the Singkhu Glacier; (b) Annual speed profiles along the centerline (EE') of the Singkhu Glacier from 1996 to 2006.

The Skamri Glacier was reported as a surge-type glacier by Copland et al. [23], which surged prior to 1978, while the South Skamri Glacier, which is a tributary of the Skamri Glacier (Figure 8), surged in 1990 and again in 2007 [23,42]. The centerline speed profiles (Figure 8b,c) show temporal variation patterns of the surface flow of the two glaciers during 1996-2006 that were revealed from the Landsat TM and ETM+ images. During 1999-2003, the South Skamri Glacier had high surface velocities (Figure 8b), which are comparable to those during the period from 2006-2007 in Copland et al. [23] and 2007-2008 in Jiang et al. [42]. Moreover, the South Skamri Glacier advanced about $240 \mathrm{~m}$ from 1999 to 2003 (Figure 9). These indicate that this glacier might have experienced an active phase from 1999-2003. However, the velocities of the Skamri Glacier (Figure 8c) suggest that this glacier might have undergone its quiescent phase during the observation period. Additionally, the velocities of the Skamri Glacier were relatively lower than those of the South Skamri Glacier, which implies that the South Skamri Glacier was the dominant flow in the Skamri Basin from 1999-2003.

As surge-type glaciers dominate the glacier sample in the northern slope, we might expect to see lower surface velocities in the northern slope than that of the southern slope, which is dominated by 
fast-flowing and non-surging glaciers. That is to say, since surge behavior is not regional, we wouldn't expect to see more than a small number of glaciers surging at any given time, so the dominant behavior of the surge-type glaciers sample would be quiescence, which tends to be slower than even for non-surging glaciers. Due to the strong impact of the surge cycle on flow velocities, we intend to investigate glacier-specific details of their dynamic behavior in a more extended, separate study before drawing further conclusions about the causes of the spatial differences in ice velocity between glaciers on the southern and northern slopes in this region.
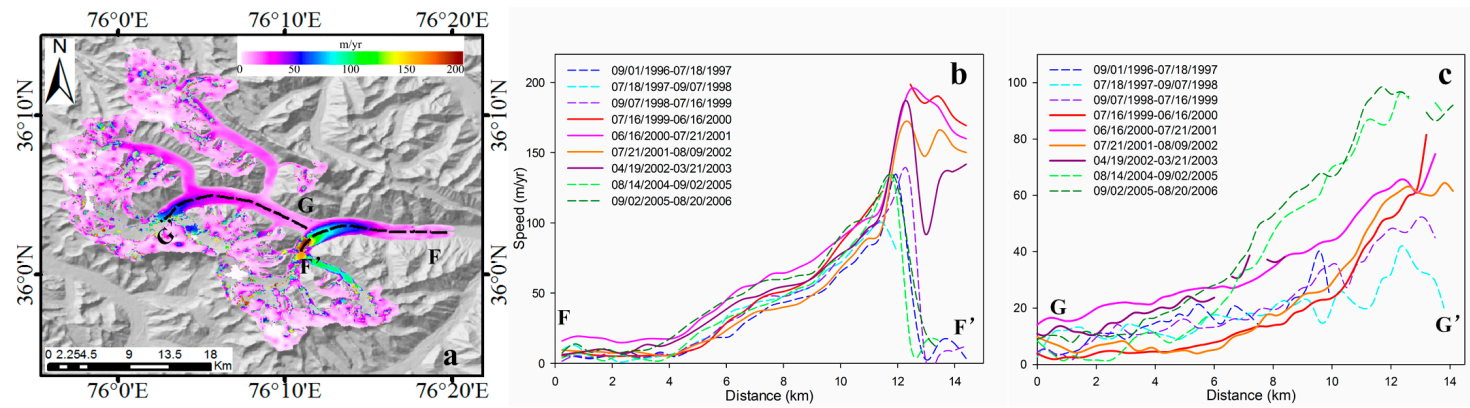

Figure 8. (a) Surface velocity over the Skamri Glacier (2000-2001) and FF' and GG' are the centerlines of the South Skamri Glacier and Skamri Glacier; (b) Annual speed profiles along the centerline (FF') of the South Skamri Glacier from 1996 to 2006; and (c) Annual speed profiles along the centerline (GG') of the Skamri Glacier from 1996 to 2006.

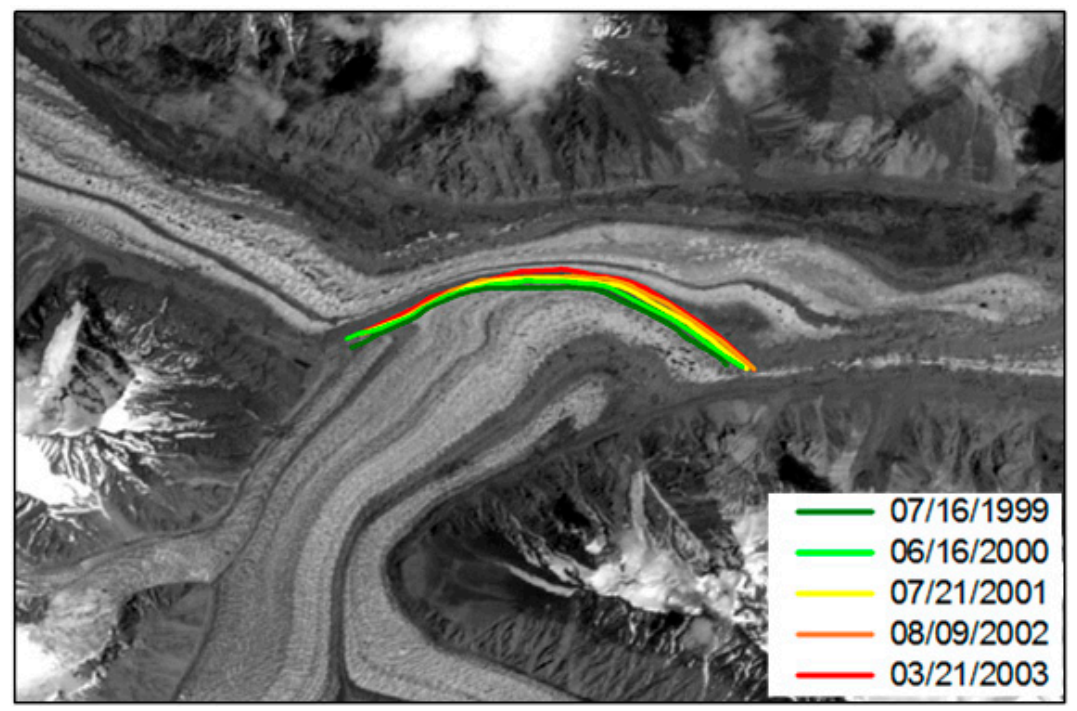

Figure 9. The frontal changes of the South Skamri Glacier from 1999 to 2003, the background is the Landsat ETM+ image acquired on 16 July 1999.

\subsection{Interpretation of the Velocity Differences between Glaciers on the Southern and Northern Slopes}

As presented in Table 2, most of the glaciers on the southern slope flowed faster than the northern slope glaciers during the observation period. To investigate the possible factors for differences in ice speed between glaciers on the southern and northern slopes, we evaluated the dependence of the average annual speeds of 24 glaciers over the study area on the topographic factors (area, length, mean width, median elevation, mean slope and mean aspect) and debris cover. We excluded the Skamri Glacier in our analysis since the South Skamri glacier was actively surging during the study period. A linear regression analysis was employed to calculate the correlation coefficient (R) between the glacier velocity and each topographic factor. Surface velocity parameters were obtained from average velocity results of 1999-2002 that limited to the lower 30\% of the glacier length along the 
centerline for each glacier, in which there are relatively reliable velocity data for most glaciers. The area, length, median elevation, mean slope and mean aspect of each glacier are derived from the RGI v5.0 [24]. Figure 10 indicates the relationships (the 95\% confidence interval) between the observed average velocity and the morphometric indices.
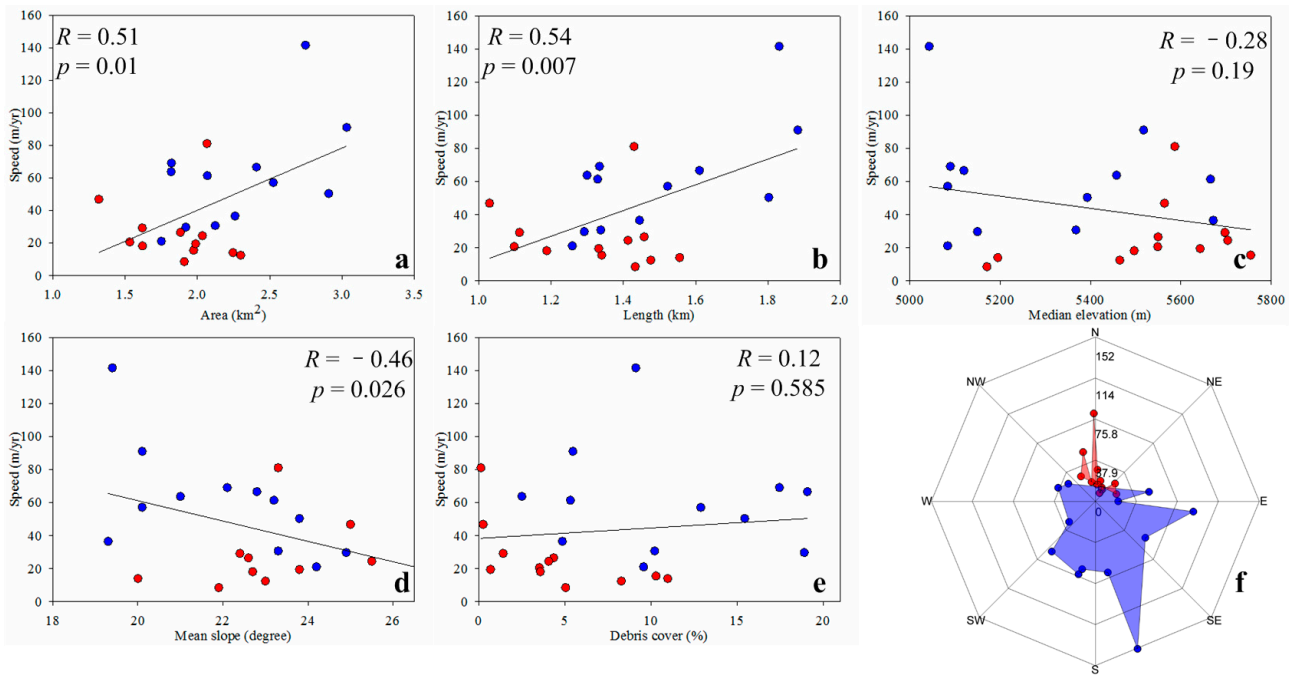

Figure 10. Correlations between glacier speed and individual topographic factors and glaciological characteristics: (a) area; (b) length; (c) median elevation; (d) mean slope of a glacier; (e) debris cover; and (f) mean aspect of a glacier. It should be noted that the area and length in $(\mathbf{a}, \mathbf{b})$ are plotted on a logarithmic axis. The blue points represent southern slope glaciers; the red points represent northern slope glaciers. $R$ is the linear correlation coefficient and $p$ is the significance level of the respective relation.

Overall, a moderate positive correlation was found between the glacier area and the glacier speed $(R=0.51, p=0.01<0.05$, Figure 10a) and a similar correlation for the glacier length $(R=0.54, p=0.007<0.05$, Figure 10b). The mean width of the glacier (glacier area/glacier length) is weakly correlated with glacier speed $(R=0.47, p=0.021<0.05$, Supplementary Figure S6). However, the median elevation $(R=-0.28, p=0.19>0.05$, Figure $10 \mathrm{c})$ is not a significant control on glacier velocity. The mean slope $(R=-0.46, p=0.026<0.05$, Figure $10 \mathrm{~d})$ is weakly anti-correlated glacier velocity. It should be noted that areas (lengths) of most of the glaciers on the southern slope are much larger (longer) than those on the northern slope as shown in Figure 10a (Figure 10b). Therefore, different glacier size (areas and lengths) may be one of the primary reasons for spatial differences in ice velocity between glaciers on the southern and northern slopes in this region.

As a key component of a glacier system, debris cover might also affect glacial dynamics [28]. Debris-covered glaciers were widely found in the Himalaya-Karakoram mountain range with more than $20 \%$ debris-cover [28]. Several studies have reported that debris cover had a protective effect on the ablation rates $[4,28,45]$ and the velocity of debris-covered ice was lower than clean ice in the Everest region and Bhutan [5,46]. Scherler et al. [28] presented spatially variable impacts of debris cover on glacier dynamics in the Greater Himalaya: quasi-stagnant glaciers (surface velocity less than $2.5 \mathrm{~m}$ /year) have high debris cover ( $>40 \%$ on average) and stable glacier fronts in the Central Himalaya, whereas there is no uniform pattern of the distribution of stagnant debris-covered glaciers in the Karakoram. In this study, similar with the results presented by Scherler et al. [28], we find that the percentage of debris cover is not significantly correlated with glacier velocity $(R=0.12, p=0.585>0.05)$ as shown in Figure 10e in which the percentage of debris cover for 24 glaciers was generated from Landsat ETM+ band4/band5-ratio images (see Supplementary Figure S7). These regional differences imply a complex response of glacier dynamics to debris cover that is probably dependent on different topographic conditions and highlights the need for a comprehensive investigation in the near future. 
Additionally, the aspect of a mountain glacier affects the solar radiation received by the glacier surface and is a potential influencing factor in glacier motion, particularly for a glacier system located on both the southern and northern slopes. Figure $10 \mathrm{f}$ illustrates that the mean aspects of glaciers on the northern slope are mainly towards the northwest to northeast, whereas the glaciers on the southern slope are mainly southwest to southeast-facing, except for four glaciers. Moreover, most of the southern-slope glaciers had higher flow velocities (Figure 10f) as they received more direct solar radiance [47]. This implies a stronger melting over the glacier surface, which should produce more meltwater flowing to the glacier bedrock through crevasses and moulins [48]. The meltwater can increase water pressure at the bedrock interface and reduce basal friction, which promotes basal sliding and thus increases the ice flow [49-52]. We just provided a qualitative explanation in this study, and there was no quantitative analysis performed due to that we have no solar radiation data of each glacier.

In addition, the multiple linear regression (MLR) analysis was also employed to examine the relationship between the glacier speed and two or more morphometric factors by fitting a linear equation to observed data. The area, length and mean width all reflect the size of a glacier, and the area is related to the length and mean width. Therefore, the area was selected to involve in the MLR analysis. Table 3 revealed the effects of variable morphometric on the glacier speed which are generally consistent with those revealed by a linear regression analysis (Figure 10). The result shows a significant correlation between glacier speed and the area at the $95 \%$ confidence interval $(p=0.019<0.05$, Table 3$)$. It should be noted that the mean slope of the glacier is not significantly correlated with the glacier velocity in the MLR analysis, while it is weakly anti-correlated (Figure 10d) with the glacier velocity in a linear regression analysis. This is mainly related to that the mean slope has a very small effect on ice flow when considering multiple factors. The median elevation, debris cover and mean aspect are not significantly correlated with the glacier speed. The morphological analysis we have performed in this study has not revealed a dependence of averaged flow velocities on any topographic parameter apart from glacier size. It should be noted that both the linear regression analysis and the MLR analysis are limited to these set of observations over studied glaciers during 1999-2003 and can't be generalized for the entire Karakoram. More such analysis is required in the future to establish a clear relationship between glacier velocity and factors in the Karakoram.

Table 3. Summary of the multiple linear regression analysis in the SPSS software package (T-value $(t)$ and $p$-value are two parameters obtained from the $t$-test).

\begin{tabular}{ccccc}
\hline Variable & Parameter Estimate & Standard Error & $\boldsymbol{t}$ & $\boldsymbol{p}$-Value \\
\hline area & 0.61 & 0.024 & 2.576 & 0.019 \\
median elevation & -0.041 & 0.035 & -1.146 & 0.267 \\
mean slope & -1.878 & 2.877 & -0.653 & 0.522 \\
debris cover & 0.071 & 0.043 & 1.643 & 0.118 \\
mean aspect & -1.226 & 1.388 & -0.883 & 0.389 \\
\hline
\end{tabular}

\subsection{Glacier Motion Mechanism}

Basal sliding and internal deformation are two major types of glacier motion mechanisms [23]. Generally, the surface velocity variations along glacier transverse profiles have been used to infer dominant motion mechanisms $[19,23,42]$. When the velocities are high and relatively constant in the glacier centre but rapidly reduced close to the glacier margins, the glacier motion mechanisms are of the basal sliding type. If the ice flow regime is dominated by internal deformation, surface velocities are generally low and gradually increase from the glacier margins to the centre in a parabolic pattern.

The transverse profiles of average annual velocities of the Baltoro and Siachen glaciers are presented in Figures 11 and 12, respectively. From a visual inspection, it is evident that the speeds increased from the margins to the centre. The speed transverse profiles $\mathrm{T} 1, \mathrm{~T} 2$, and $\mathrm{T} 3$ across the upper and middle ablation zones of the two glaciers (see Figures 4 and 6) all exhibited not only a rapid increase away from both glacier margins but were high and relatively constant in the glacier 
centres as shown in Figures 11a-c and 12a-c. This indicates that basal sliding is the predominant flow mechanism in these upper and middle areas; however, the transverse profile T4 located on the glacier snout (see Figures 4 and 6) shows quite a different flow pattern from those in T1-T3, where speeds are relatively low and gradually rose to a peak in the centre of the glacier. Such velocity patterns suggest that internal deformation dominates close to the terminus rather than basal sliding. Similar discussions were reported by Copland et al. [23] and Quincey et al. [19]. Figures 11 and 12 also show that the velocities of the middle and upper zones of the two glaciers are larger than the downstream zone. This is mainly due to the larger mass accumulation at the middle and upper zones than downstream area [26].
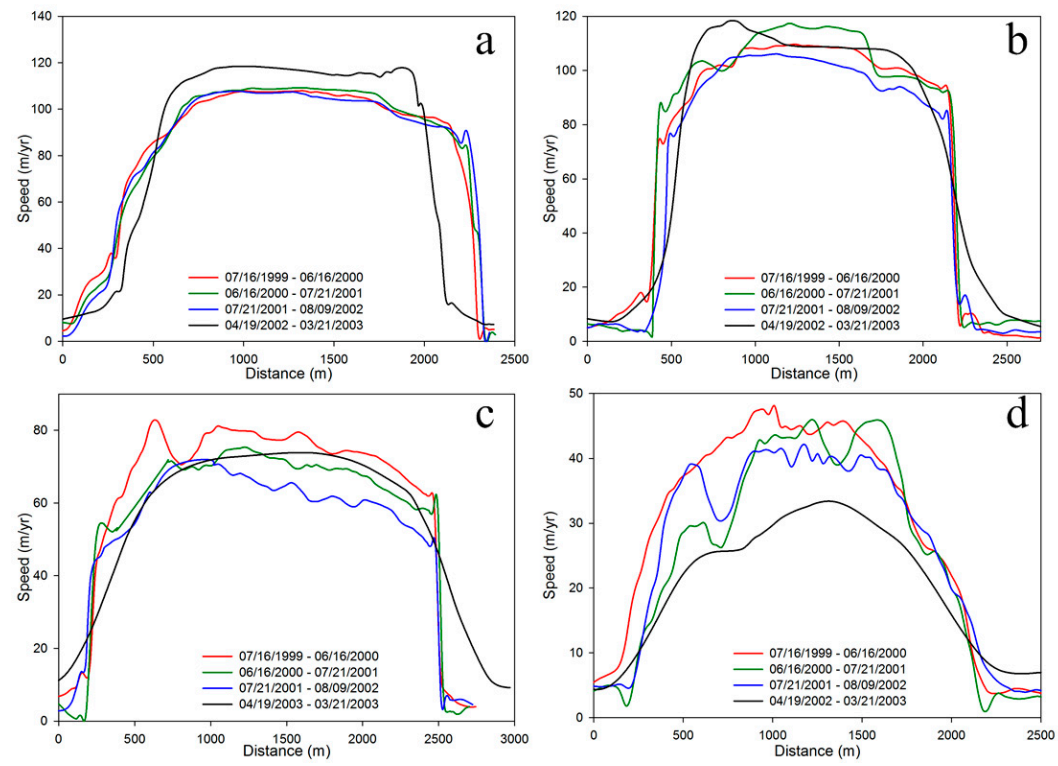

Figure 11. Transverse speed profiles of the Baltoro Glacier. Profile locations are depicted in Figure 3a. (a-d) The comparison of annual surface velocity change along the transverse profiles of T1, T2, T3, and T4, respectively.
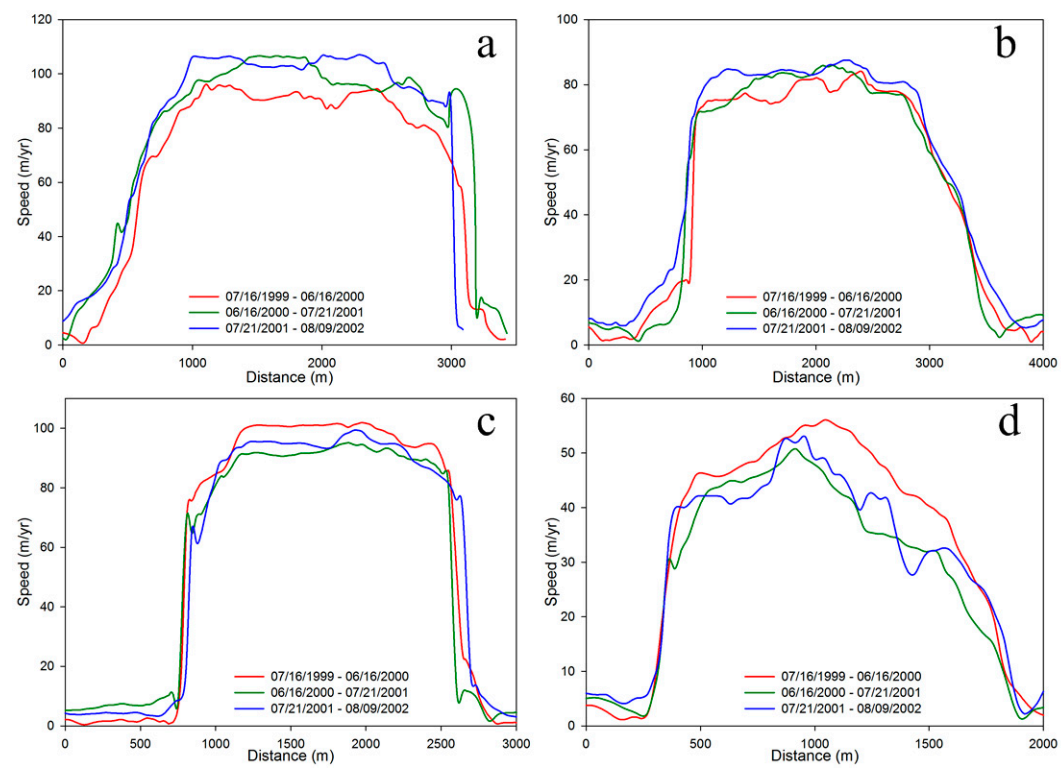

Figure 12. Transverse speed profiles of the Siachen Glacier. Profile locations are depicted in Figure 5 a. (a-d) The comparison of annual surface velocity change along the transverse profile T1, T2, T3, and T4, respectively. 
We also analysed the transverse profiles of the average annual velocities of the Biafo Glacier (Supplementary Figure S8), Panmah Glacier and its tributary Choktoi Glacier (Supplementary Figure S9), Skamri Glacier (Supplementary Figure S10), North Gasherbrum Glacier (Supplementary Figure S11) and Singkhu Glacier (Supplementary Figure S12), which suggest that motion mechanisms of these glaciers are similar with the Baltoro and Siachen glaciers. Therefore, it could be inferred that basal sliding might be the predominant motion mechanism across the middle and upper regions for most nonsurge-type and surge-type glaciers in the Central Karakoram, whereas internal deformation is dominant close to the glacier terminus. Additionally, the active surge-type glacier (southern Skamri glacier) might be dominated by the similar ice-motion mechanisms with nonsurge-type glaciers, which is in agreement with results in Copland et al. [23] and Jiang et al. [42], however, this predominant motion mechanism of quiescent surge-type glaciers have been not reported in the Central Karakoram in previous literatures.

\section{Conclusions}

In this study, the spatial and temporal variability in the surface velocity during 1999-2003 over the Central Karakoram was characterized by an analysis of the inter-annual glacier velocity fields, which extends the period of measurements of glacier velocities in this region. The velocity fields were retrieved using a cross-correlation based approach with four pairs of Landsat ETM+ panchromatic images. The results indicated that the large-sized glaciers flowed faster than the smaller glaciers and the highest surface velocity reached up to approximately $200 \mathrm{~m} /$ year and occurred on the Biafo glacier and the South Skamri Glacier. The average annual velocity revealed that most glaciers on the southern slope flowed faster than those of the northern slope. This difference might be attributed to the different glacier sizes on the southern and northern slopes. In addition, the observed differences in flow velocities between the northern and southern glaciers might be dominated by the phase of the surge cycle, rather than morphometric factors. Determining these causes requires investigation of velocities over longer time periods than we have here, and we intend to investigate this further in future studies. Moreover, a new surging event for the South Skamri Glacier was identified in the study period by investigating the glacier frontal changes and the longer-term time series of the surface velocities between 1996 and 2006. Finally, from the transverse profiles of the glacier velocity, we inferred that the motion regime of the middle and upper regions of both glaciers was dominated by basal sliding, whereas internal deformation was a more dominant motion mechanism closer to the glacier terminus.

Supplementary Materials: The following are available online at www.mdpi.com/2072-4292/9/10/1064/s1. Figure S1. Four annual velocity fields over the central Karakoram from 1999 to 2003. a: 1999-2000; b: 2000-2001; c: 2001-2002; d: 2002-2003.The blue dashed line marks the boundary between the southern and northern slopes glaciers. Abbreviations denote: $\mathrm{Br}=$ Braldu Glacier, Sk = Skamri Glacier, SL = Sarpo Laggo Glacier, $\mathrm{NG}=$ North Gasherbrum Glacier, Ur = Urbak Glacier, Sh = Singkhu Glacier, Ky = Kyagar Glacier, Si = Siachen Glacier, $\mathrm{Ka}=$ Kaberi Glacier, $\mathrm{Bt}=$ Baltoro Glacier, $\mathrm{Pa}=$ Panmah Glacier, Bi = Biafo Glacier; Figure S2. Four annual velocity fields of the North Gasherbrum Glacier from 1999-2003. (a) 1999-2000; (b) 2000-2001; (c) 2001-2002; and (d) 2002-2003. The background is the hillshade image of SRTM DEM. CC' is the centerline of the glacier; Figure S3. Annual speed profiles along the centerline $\left(C^{\prime}\right)$ of the North Gasherbrum Glacier. The centerline location is indicated by the dashed line in Figure S2a; Figure S4. Four annual velocity fields of the Singkhu Glacier from 1999-2003. (a) 1999-2000; (b) 2000-2001; (c) 2001-2002; and (d) 2002-2003. The background is the hillshade image of SRTM DEM. DD' is the centerline of the glacier; Figure S5. Annual speed profiles along the centerline (DD') of the Singkhu Glacier. The centerline location is indicated by the dashed line in Figure S4a; Figure S6. Correlation between the glacier speed and the mean width. $R$ is the linear correlation coefficient and $p$ is the significance level of the respective relation; Figure S7. Distribution of debris cover derived from Landsat ETM+ band 4/band5-ratio images. The blue dashed line marks the boundary between the southern and northern slopes glaciers. Abbreviations: $\mathrm{Br}=$ Braldu Glacier, Sk = Skamri Glacier, SL = Sarpo Laggo Glacier, $\mathrm{NG}=$ North Gasherbrum Glacier, Ur = Urbak Glacier, Sh = Singkhu Glacier, Ky = Kyagar Glacier, Si = Siachen Glacier, $\mathrm{Ka}=$ Kaberi Glacier, Bt = Baltoro Glacier, $\mathrm{Pa}=$ Panmah Glacier, Bi = Biafo Glacier; Figure S8. (a) Surface velocity over the Biafo Glacier (1999-2000); (b-d) Comparison of annual surface speed change along transverse profiles T1, T2 and T3. Profile locations are depicted in (a). Date format is month/day/year; Figure S9. (a) Surface velocity over the Panmah Glacier (2001-2002) which includes two tributary glaciers of Choktoi and Nobande Sobonde; (b-d) Comparison of annual surface speed change along transverse profiles T1, T2 and T3. Profile 
locations are depicted in (a). Date format is month/day/year; Figure S10. (a) Surface velocity over the Skamri Glacier (2000-2001); (b,c) Comparison of annual surface speed change along transverse profiles T1 and T2. Profile locations are depicted in (a). Date format is month/day/year; Figure S11. (a) Surface velocity over the North Gasherbrum Glacier (2001-2002); (b,c) Comparison of annual surface speed change along transverse profiles T1 and T2. Profile locations are depicted in (a). Date format is month/day/year; Figure S12. (a) Surface velocity over the Singkhu Glacier (2001-2002); (b-d) Comparison of annual surface speed change along transverse profiles T1, T2 and T3. Profile locations are depicted in (a). Date format is month/day/year.

Acknowledgments: The work in this study was supported by the National Key R \& D Program of China (grant No. 2017YFA0603103), the National Natural Science Foundation of China (grant No. 41431070, 41590854, and 41621091); and the Key Research Program of Frontier Sciences, CAS (grant No. QYZDB-SSW-DQC027 and QYZDJ-SSW-DQC042). The authors would like to express their sincere thanks to the guest editors and three anonymous reviewers for their insightful comments and suggestions. The authors would like to thank the USGS for providing free Landsat ETM+ images and SRTM DEM, and thank Sebastien Leprince and Melanie Rankl for providing the COSI-Corr software package and the velocity data.

Author Contributions: Liming Jiang conceived and designed the experiments; Yongling Sun performed the experiments and carried out the data analysis with the significant contributions of Liming Jiang. Lin Liu and Hansheng Wang made substantial contributions to the analysis and interpretation of the results; Yafei Sun focused on statistical computations; and Yongling Sun and Liming Jiang wrote the paper.

Conflicts of Interest: The authors declare no conflict of interest.

\section{References}

1. Rankl, M.; Kienholz, C.; Braun, M. Glacier changes in the Karakoram region mapped by multimission satellite imagery. Cryosphere 2014, 8, 977-989. [CrossRef]

2. Gardelle, J.; Arnaud, Y.; Kääb, A. Region-wide glacier mass balances over the Pamir-Karakoram-Himalaya during 1999-2011. Cryosphere 2013, 7, 1263-1286. [CrossRef]

3. Yao, T.; Yang, X.; Duan, K.; Zhao, H.; Xu, B.; Pu, J.; Lu, A.; Xiang, Y. Different glacier status with atmospheric circulations in Tibetan Plateau and surroundings. Nat. Clim. Chang. 2012, 2, 663-667. [CrossRef]

4. Gardelle, J.; Berthier, E.; Arnaud, Y. Slight mass gain of Karakoram glaciers in the early twenty-first century. Nat. Geosci. 2012, 5, 322-325. [CrossRef]

5. Bolch, T.; Kulkarni, A.; Kääb, A.; Huggel, C.; Paul, F.; Cogley, J.G.; Frey, H.; Kargel, J.S.; Fujita, K.; Scheel, M.; et al. The state and fate of Himalayan glaciers. Science 2012, 336, 310-314. [CrossRef] [PubMed]

6. Gardner, A.S.; Moholdt, G.; Cogley, J.G.; Wouters, B.; Arendt, A.A.; Wahr, J.; Berthier, E.; Hock, R.; Pfeffer, W.T.; Kaser, G. A reconciled estimate of glacier contributions to sea level rise: 2003 to 2009. Science 2013, 340, 852-857. [CrossRef] [PubMed]

7. Hewitt, K. The Karakoram anomaly? Glacier expansion and the 'elevation effect', Karakoram Himalaya. Mt. Res. Dev. 2005, 25, 332-340. [CrossRef]

8. Kargel, J.S.; Leonard, G.J.; Bishop, M.P.; Kääb, A.; Raup, B.H. (Eds.) Global Land Ice Measurements from Space; Springer: Berlin, Germany, 2014.

9. Searle, M.P. Geology and Tectonics of the Karakoram Mountains; Wiley: New York, NY, USA, 1991.

10. Kääb, A.; Treichler, D.; Nuth, C.; Berthier, E. Brief communication contending estimates of 2003-2008 glacier mass balance over the Pamir-Karakoram-Himalaya. Cryosphere 2015, 9, 557-564. [CrossRef]

11. Immerzeel, W.W.; van Beek, L.P.H.; Bierkens, M.F.P. Climate change will affect the Asian water towers. Science 2010, 328, 1382-1385. [CrossRef] [PubMed]

12. Minora, U.; Bocchiola, D.; D'Agata, C.; Maragno, D.; Mayer, C.; Lambrecht, A.; Mosconi, B.; Vuillermoz, E.; Senese, A.; Compostella, C.; et al. 2001-2010 glacier changes in the central Karakoram national park: A contribution to evaluate the magnitude and rate of the "Karakoram anomaly". Cryosphere Discuss. 2013, 7, 2891-2941. [CrossRef]

13. Feng, Q. Characteristics of glacier outburst flood in the Yarkant River, Karakorum Mountains. GeoJournal 1991, 25, 255-263. [CrossRef]

14. Kääb, A. Combination of SRTM3 and repeat ASTER data for deriving alpine glacier flow velocities in the Bhutan Himalaya. Remote Sens. Environ. 2005, 94, 463-474. [CrossRef]

15. Mayer, C.; Fowler, A.C.; Lambrecht, A.; Scharrer, K. A surge of North Gasherbrum glacier, Karakoram, China. J. Glaciol. 2011, 57, 904-916. [CrossRef]

16. Paul, F. Revealing glacier flow and surge dynamics from animated satellite image sequences: Examples from the Karakoram. Cryosphere 2015, 9, 2201-2214. [CrossRef] 
17. Paul, F.; Strozzi, T.; Schellenberger, T.; Kääb, A. The 2015 Surge of Hispar Glacier in the Karakoram. Remote Sens. 2017, 9, 888. [CrossRef]

18. Yasuda, T.; Furuya, M. Short-term glacier velocity changes at West Kunlun Shan, Northwest Tibet, detected by Synthetic Aperture Radar data. Remote Sens. Environ. 2013, 128, 87-106. [CrossRef]

19. Quincey, D.J.; Copland, L.; Mayer, C.; Bishop, M.; Luckman, A.; Belo, M. Ice velocity and climate variations for Baltoro glacier, Pakistan. J. Glaciol. 2009, 55, 1061-1071. [CrossRef]

20. Scherler, D.; Strecker, M.R. Large surface velocity fluctuations of Biafo glacier, central Karakoram, at high spatial and temporal resolution from optical satellite images. J. Glaciol. 2012, 58, 569-580. [CrossRef]

21. Heid, T.; Kääb, A. Repeat optical satellite images reveal widespread and long term decrease in land-terminating glacier speeds. Cryosphere 2012, 6, 467-478. [CrossRef]

22. Dehecq, A.; Gourmelen, N.; Trouve, E. Deriving large-scale glacier velocities from a complete satellite archive: Application to the Pamir-Karakoram-Himalaya. Remote Sens. Environ. 2015, 162, 55-66. [CrossRef]

23. Copland, L.; Pope, S.; Bishop, M.P.; Shroder, J.F., Jr.; Clendon, P.; Bush, A.; Kamp, U.; Seong, Y.B.; Owen, L.A. Glacier velocities across the central Karakoram. Ann. Glaciol. 2009, 50, 1-9. [CrossRef]

24. Arendt, A.; Bliss, A.; Bolch, T.; Cogley, J.; Gardner, A.; Hagen, J.; Hock, R.; Huss, M.; Kaser, G.; Kienholz, C. Randolph Glacier Inventory-A Dataset of Global Glacier Outlines: Version 5.0; Global Land Ice Measurements from Space: Boulder, CO, USA, 2015.

25. Seonga, Y.B.; Owena, L.A.; Bishopb, M.P.; Bushc, A.; Clendond, P.; Coplande, L.; Finkelf, R.; Kampg, U.; Shroder, J.F., Jr. Quaternary glacial history of the central Karakoram. Quat. Sci. Rev. 2007, 26, 3384-3405. [CrossRef]

26. Hewitt, K.; Wake, C.P.; Young, G.J.; David, C. Hydrological investigations at Biafo glacier, Karakoram Range, Himalaya; an important source of water for the Indus River. Ann. Glaciol. 1989, 13, 103-108. [CrossRef]

27. Kumar, V.; Venkataramana, G.; Hogda, K.A. Glacier surface velocity estimation using SAR interferometry technique applying ascending and descending passes in Himalayas. Int. J. Appl. Earth Obs. Geoinf. 2011, 13, 545-551. [CrossRef]

28. Scherler, D.; Bookhagen, B.; Strecker, M.R. Spatially variable response of Himalayan glaciers to climate change affected by debris cover. Nat. Geosci. 2011, 4, 156-159. [CrossRef]

29. Owen, L.A.; Derbyshire, E. Glacially deformed diamictons in the Karakoram mountains, Northern Pakistan. In Glaciotectonics: Forms and Processes; Croot, D.G., Ed.; Balkema: Rotterdam, The Netherlands, 1988; pp. 149-176.

30. Rankl, M.; Braun, M. Glacier elevation and mass changes over the Central Karakoram region estimated from TanDEM-X and SRTM/X-SAR digital elevation models. Ann. Glaciol. 2016, 57, 273-281. [CrossRef]

31. Zhang, C.; Li, W.; Travis, D. Gaps-fill of SLC-off Landsat ETM+ satellite image using a geostatistical approach. Int. J. Remote Sens. 2007, 28, 5103-5122. [CrossRef]

32. United States Geological Survey (USGS) EarthExplorer. Available online: https:/ / earthexplorer.usgs.gov / (accessed on 6 July 2013).

33. Leprince, S.; Barbot, S.; Ayoub, F.; Avouac, J.-P. Automatic and precise ortho-rectification, coregistration, and subpixel correlation of satellite images, application to ground deformation measurements. EEE Trans. Geosci. Remote Sens. 2007, 45, 1529-1558. [CrossRef]

34. Scherler, D.; Leprince, S.; Strecker, M. Glacier-surface velocities in alpine terrain from optical satellite imagery-Accuracy improvement and quality assessment. Remote Sens. Environ. 2008, 112, 3806-3819. [CrossRef]

35. Motagh, M.; Wetzel, H.-U.; Roessner, S.; Kaufmann, H. The Inylchek glacier in Kyrgyzstan, central Asia: Insight on surface kinematics from optical remote sensing imagery. Remote Sens. 2014, 6, 841-856.

36. Zhou, Y.; Li, Z.; Li, J.I.A. Slight glacier mass loss in the Karakoram region during the 1970s to 2000 revealed by KH-9 images and SRTM DEM. J. Glaciol. 2017, 63, 331-342. [CrossRef]

37. Ayoub, F.; Leprince, S.; Avouac, J.-P. User's Guide to COSI-Corr: Co-Registration of Optically Sensed Images and Correlation. Available online: http:/ / www.tectonics.caltech.edu/slip_history/spot_coseis/pdf_files / CosiCorr-Guide2015a.pdf (accessed on 27 July 2015).

38. Koblet, T.; Gärtner-Roer, I.; Zemp, M.; Jansson, P.; Thee, P.; Haeberli, W.; Holmlund, P. Reanalysis of multi-temporal aerial images of Storglaciären, Sweden (1959-99)—Part 1 Determination of length, area, and volume changes. Cryosphere 2010, 4, 333-343. [CrossRef] 
39. Bolch, T.; Pieczonka, T.; Benn, D.I. Multi-decadal mass loss of glaciers in the Everest area (Nepal Himalaya) derived from stereo imagery. Cryosphere 2011, 5, 349-358. [CrossRef]

40. Copland, L.; Sylvestre, T.; Bishop, M.P.; Shroder, J.F.; Seong, Y.B.; Owen, L.A.; Bush, A.; Kamp, U. Expanded and recently increased glacier surging in the Karakoram. Arct. Antarct. Alp. Res. 2011, 43, 503-516. [CrossRef]

41. Quincey, D.J.; Braun, M.; Glasser, N.F.; Bishop, M.P.; Hewitt, K.; Luckman, A. Karakoram glacier surge dynamics. Geophys. Res. Lett. 2011, 38, L18504. [CrossRef]

42. Jiang, Z.-L.; Liu, S.-Y.; Peters, J.; Lin, J.; Long, S.-C.; Han, Y.-S.; Wang, X. Analyzing Yengisogat glacier surface velocities with ALOS PALSAR data feature tracking, Karakoram, China. Environ. Earth Sci. 2012, 67, 1033-1043. [CrossRef]

43. Quincey, D.J.; Glasser, N.F.; Cook, S.J.; Luckman, A. Heterogeneity in Karakoram glacier surges. J. Geophys. Res. Earth Surf. 2015, 120, 1288-1300. [CrossRef]

44. Kotlyakov, V.M. Atlas Snezhno-Ledovykh Resursa Mira [World Atlas of Snow and Ice Resources]; Institute of Geography, Russian Academy of Sciences: Moscow, Russian, 1997; Volume 2. (In English and Russian)

45. Mihalcea, C.; Mayer, C.; Diolaiuti, G.; D’agata, C.; Smiraglia, C.; Lambrecht, A.; Vuillermoz, E.; Tartari, G. Spatial distribution of debris thickness and melting from remote-sensing and meteorological data, at debris-covered Baltoro glacier, Karakoram, Pakistan. Ann. Glaciol. 2008, 48, 49-57. [CrossRef]

46. Quincey, D.J.; Luckman, A.; Benn, D. Quantification of Everest region glacier velocities between 1992 and 2002, using satellite radar interferometry and feature tracking. J. Glaciol. 2009, 55, 596-606. [CrossRef]

47. Jiskoot, H.; Curran, C.J.; Tessler, D.L.; Shenton, L.R. Changes in Clemenceau Icefield and Chaba Group glaciers, Canada, related to hypsometry, tributary detachment, length-slope and area-aspect relations. Ann. Glaciol. 2009, 50, 133-143. [CrossRef]

48. Fountain, A.G.; Walder, J.S. Water flow through temperate glaciers. Rev. Geophys. 1998, 36, $299-328$. [CrossRef]

49. Kamb, B.; Engelhardt, H.; Fahnestock, M.A.; Humphrey, N.; Meier, M.; Stone, D. Mechanical and hydrologic basis for the rapid motion of a large tidewater glacier: 2. Interpretation. J. Geophys. Res. Solid Earth 1994, 99, 15231-15244. [CrossRef]

50. Zwally, H.J.; Abdalati, W.; Herring, T.; Larson, K.; Saba, J.; Steffen, K. Surface melt-induced acceleration of Greenland ice-sheet flow. Science 2002, 297, 218-222. [CrossRef] [PubMed]

51. Hewitt, I.J. Seasonal changes in ice sheet motion due to melt water lubrication. Earth Planet. Sci. Lett. 2013, 371-372, 16-25. [CrossRef]

52. Cuffey, K.M.; Paterson, W.S.B. The Physics of Glaciers; Elsevier: Burlington, MA, USA, 2010. 